\title{
産学協同研究についで
}

\section{大和田 国男}

\section{1. はじめに}

先の本学会誌（昭和 59 年 1 月号）に「産学協同研 究」と題して産学協同研究の意義及び，当時の実施情 況, すなわち文部省の受託研究等の制度, (財) 日本学 術振興会産学協力研究委員会, 日本機械学会研究協力 部会を紹介し, 産学協同研究の必要性を述べた.つい で精機学会 (現精密工学会) 50 周年記念事業の一つ として学会の組織内に産学協同研究協議会を設置する ことを報告しだ1).今回はこれら事業の央施状況を紹 介する。

\section{2. 精密工学会産学協同研究協議会 による産学協同研究}

産学協同研究協議会が設置（昭和 58 年 12 月）され てから 7 か年が経過した. この間, 協議会活動として 毎年数件にわたる研究協力分科会が設置され, 産側の 研究者之学側 (研究機関) の研究者との協同研究が進 められている.

産学協同研究協議会の運営は, (1)あくまで「産」 主導ですすめる，(2)産側の二ーズ，学側のシーズが それぞれらをく連結され, 多数の企業が参画出来, よ り効果が発揮されやすいようにする, (3)学会の特徵 である豊富な頭脳集団を十分活用できるよらにする, (4)精密工学会の従来の「専門委員会」「分科会」に比 ベてより実戦的，かつ実務的な研究に力が入れられ， 短期間に成果が上がるよう研究テーマに対して予算の 配分が考慮されている。

これまでに次の研究協力分科会が設置され，協同研 究がすすめられて来た.

* 原稿受付 平成 2 年 12 月 20 日

** 正会 員 (株)不二越（東京都港区浜松町 2-4-1)
昭和 59 年度研究協力分科会

\begin{tabular}{|c|c|c|}
\hline No. & 分 科 会 名 & 委員長名 \\
\hline 1 & $\begin{array}{l}\text { 高度生産自動化のためのプロダク } \\
\text { ト・モデリングシステムの開発研究 } \\
\text { 協力分科会 }\end{array}$ & $\begin{array}{l}\text { 佐 田 登 志 夫 } \\
\text { (理化学研究所) }\end{array}$ \\
\hline 2 & $\begin{array}{l}\text { 大型鋳鍛造品自動ケ引システムの開 } \\
\text { 発研究協力分科会 }\end{array}$ & $\begin{array}{l}\text { 岸 浪建 史 } \\
\text { (北海道大学) }\end{array}$ \\
\hline
\end{tabular}

昭和 60 年度研究協力分科会

\begin{tabular}{|c|c|c|}
\hline 1 & $\begin{array}{l}\text { 汎用自動部品供給システム研究協力 } \\
\text { 分科会 }\end{array}$ & $\begin{array}{l}\text { 横 山 恭 男 } \\
\text { (金沢大学) }\end{array}$ \\
\hline 2 & $\begin{array}{l}\text { 組立作業データバンクの作成研究協 } \\
\text { 力分科会 }\end{array}$ & $\begin{array}{l}\text { 牧 野 } \\
\text { (山梨大学) }\end{array}$ \\
\hline 3 & $\begin{array}{l}\text { 超精密切削加工金属鏡のインプロセ } \\
\text { ス計測と加工制御研究協力分科会 }\end{array}$ & $\begin{array}{l}\text { 河 野 嗣 男 } \\
\text { (都立科学技術大 } \\
\text { 学) }\end{array}$ \\
\hline 4 & $\begin{array}{l}\text { 超精密ダイヤモンド妡削加工用工具 } \\
\text { 刃先の評価に関する研究協力分科会 }\end{array}$ & $\begin{array}{l}\text { 小 林 昭 } \\
\text { (HiMEP 研究所) }\end{array}$ \\
\hline 5 & $\begin{array}{l}\text { 難削材加工一金型用高硬度材及び } \\
\text { FRP, FRM, 七ラミックス等の新 } \\
\text { 素材の仕上加工一研究協力分科会 }\end{array}$ & $\begin{array}{l}\text { 鳴 瀧 則 彦 } \\
\text { (広島大学) }\end{array}$ \\
\hline 6 & $\begin{array}{l}\text { 新素材, 難削材（ファインセラミッ } \\
\text { クス）の精密加工技術の開発とその } \\
\text { 評価法の研究協力分科会 }\end{array}$ & $\begin{array}{l}\text { 今 中 治 } \\
\text { (富山職業訓練短 } \\
\text { 期大学校) }\end{array}$ \\
\hline
\end{tabular}

昭和 61 年度研究協力分科会

\begin{tabular}{|c|c|c|}
\hline 1 & $\begin{array}{l}\text { 強靱セラミックスの高能率高精度加 } \\
\text { 工法の開発研究協力分科会 }\end{array}$ & $\begin{array}{l}\text { 井 川 直 哉 } \\
\text { (大阪大学) }\end{array}$ \\
\hline 2 & $\begin{array}{l}\text { 被覆工具の性能評価と新工具開発の } \\
\text { ための基礎研究協力分科会 }\end{array}$ & $\begin{array}{l}\text { 山口勝 美 } \\
\text { (名古屋大学) }\end{array}$ \\
\hline 3 & $\begin{array}{l}\text { 極限環境（超高真空）における機械 } \\
\text { 要素に関する研究協力分科会 }\end{array}$ & $\begin{array}{l}\text { 宮 川 行 雄 } \\
\text { (法政大学) }\end{array}$ \\
\hline 4 & $\begin{array}{l}\text { 高精度非接触三次元測定機の研究協 } \\
\text { 力分科会 }\end{array}$ & $\begin{array}{l}\text { 塚 田 忠 夫 } \\
\text { (東京工業大学) }\end{array}$ \\
\hline 5 & $\begin{array}{l}\text { 電解放電複合加工研削加工法に扣け } \\
\text { る加工メカニズム究明 (セラミック } \\
\text { ス, 難削材等) 研究協力分科会 }\end{array}$ & $\begin{array}{l}\text { 横 川 和 } \\
\text { (明治大学) }\end{array}$ \\
\hline
\end{tabular}


昭和 62 年度研究協力分科会

\begin{tabular}{|c|c|c|}
\hline 1 & $\begin{array}{l}\text { 高精度ラージスケールディメンショ } \\
\text { ン測定技術に関する研究協力分科会 }\end{array}$ & $\begin{array}{l}\text { 大 園 成 大 } \\
\text { (東京大学) }\end{array}$ \\
\hline 2 & $\begin{array}{l}\text { 十の開発と評 } \\
\text { 会 }\end{array}$ & $\begin{array}{l}\text { 立不 哲 也 } \\
\text { (機峨技術研究所) }\end{array}$ \\
\hline 3 & $\begin{array}{l}\text { 精密小形変速機構のためのトラク } \\
\text { ション・ドライブの研究協力分科会 }\end{array}$ & $\begin{array}{l}\text { 渡 辺 } \\
\text { (東北大学:) }\end{array}$ \\
\hline 4 & $\begin{array}{l}\text { 高剛性静圧空気軸受の研究協力分科 } \\
\text { 会 }\end{array}$ & $\begin{array}{l}\text { 稲 崎 } \\
\text { (慶伈大学) }\end{array}$ \\
\hline
\end{tabular}

昭和 63 年度研究協力分科会

\begin{tabular}{|c|c|c|}
\hline 1 & $\begin{array}{l}\text { 製品の機能や生産性の事前評価に基 } \\
\text { ごく機械生産の高精度化研究協力分 } \\
\text { 科会 }\end{array}$ & $\begin{array}{l}\text { 佐 田登志夫 } \\
\text { (理化学研究所) }\end{array}$ \\
\hline 2 & $\begin{array}{l}\text { 精密機械熱変形の解析と評価の研究 } \\
\text { 協力分科会 }\end{array}$ & $\begin{array}{l}\text { 森 脇 俊 道 } \\
\text { (神戸大学) }\end{array}$ \\
\hline & $\begin{array}{l}\text { 研削シミュレーション技術の開発研 } \\
\text { 究協力分科会 }\end{array}$ & $\begin{array}{l}\text { 古川 勇 } \text { 川: } \\
\text { (東京都立大学) }\end{array}$ \\
\hline
\end{tabular}

1989 年度研究協力分科会

\begin{tabular}{|c|c|c|}
\hline 1 & $\begin{array}{l}\text { 積層型圧電素子を用いた機素の機能 } \\
\text { 向上と有効利用に関する研究協力分 } \\
\text { 科会 }\end{array}$ & $\begin{array}{l}\text { 箱 守 京 次 郎 } \\
\text { (東北大学) }\end{array}$ \\
\hline 2 & $\begin{array}{l}\text { 超磁歪材料のアクチュエータへの応 } \\
\text { 用に関する研究協力分科会 }\end{array}$ & $\begin{array}{l}\text { 江 田 } \\
\text { (茨城大学:) }\end{array}$ \\
\hline & $\begin{array}{l}\text { 加工に拈ける表面性状の改良に関寸 } \\
\text { る研究協力分科会 }\end{array}$ & $\begin{array}{l}\text { 吉 田 嘉 太 郎 } \\
\text { (千葉大学) }\end{array}$ \\
\hline
\end{tabular}

1990 年度研究協力分科会

\begin{tabular}{|c|c|c|}
\hline 1 & $\begin{array}{l}\text { る人間の感性に関す } \\
\text { 会 }\end{array}$ & $\begin{array}{l}\text { 小 林 昭 } \\
\text { (HiMEP 研究所) }\end{array}$ \\
\hline ? & :ズムの製作に関する & $\begin{array}{l}\text { 林 輝 } \\
\text { (東京工業大学) }\end{array}$ \\
\hline & $\begin{array}{l}\text { 㓱成技術の開発に関 } \\
\text { 合 }\end{array}$ & $\begin{array}{l}\text { 黒 部 利 次 } \\
\text { (金沢大学) }\end{array}$ \\
\hline & $\begin{array}{l}\text { ぜい性材料の超精密研削加工と評価 } \\
\text { に関する研究協力分科会 }\end{array}$ & $\begin{array}{l}\text { 宮 下 政 和 } \\
\text { (足利工業大学) }\end{array}$ \\
\hline
\end{tabular}

活動は参加企業のニーズが積極的に取り上げられ学 側 (研究機関) はこれにこたえて, 多くの研究者の頭 脳を集めて調査あるいは実験を重ねてきた。 まさに産 学協同研究の趣旨に沿った研究協力活動であった.

その結果，既に昭和 59〜62 年度の各分科会は活動 を終了し，多大の成果を上げて報告書にまとめられ， 参加企業の研究開発・製品開発の促進に多いに役立っ ている. 又, 逐次研究発表会も精密工学会主催産学協 同研究協議会企画で開催され，広く公開されて社会に 貢献している.

\section{3. 文部省政策による産学協同研究}

近年，産業界をはじめとする社会の各方面から大学
等の学術研究に対して, 具体的な諸課題の解決等のた め多様な期待と要請が奇せられている. 我が国の大学 等がその本来の使命を踏ま兄つつ幅広い研究成果の蓄 積と豊かな人材を生かして，これらの社会的要請に適 切に対応することは開かれた大学として，そのこと自 体が社会的に有意義であるのみならず，大学等の学術 研究にも有益な刺激を得ることになるので社会との協 力・連携を積極的に推進している，以下にその諸制度 を記すが，その規模は年々増加している2).

「国立大学と䟼企業との共同研究制度」

昭和 58 年度に創設され，初年度は事施大学数 21 校, 相手方企業数 52 社, 共同研究数 56 件, 受入研究 者数 66 名, 予算額 6.8 億円であったが, 平成元年度 はそれぞれ 80 校，461 社，705 件，842 名，33.7 億円 と増加している。

「受託研究制度」

2025 件，47.4 億川 (平成元年度/昭和 55 年度比 1.6 倍, 2.2 倍)

「受託研究員制度」

受入約 60 機関, 受入研究員 1099 名（1.5 倍）

「奖学奇付金制度」

受入金額 380 億円（3.7 倍）

「日本学術振興会産学協力研究委員会」

学界之産業界の第一線研究者により, 将来の技術開 発を目指す上で重要となる主題を選定し, 研究協議, 情報交換等を重ねる産学協同研究の場を提供してい る. 昭和 57 年度からは産学協力諸事業を長期的展望 の下に総合的, 組織的に推進するため総合研究連絡会 議を発足させ, その方針のもと研究分野, 課題ごとに 研究開発専門委員会を設けている. 現在活動中の委員 会として，ヒト・ゲノムに関する委員会がある.

「地域共同研究センター」

社会との協力・連携をより一層全学的に積極的に推 進するため昭和 62 年度より国立大学に専任教官, 客 員教官, 汎用的な研究設備を備えた地域共同研究セン ターを開設している.そこでは民間との共同研究，受 託研究，技術相談，技術研修が央施され，先端的技術 開発等により地域産業の活性化に貢献している.

年度別に次の地域の大学に設置された.

昭和 62 年度：3大学（富山大学, 神戸大学, 能本大 学)

昭和 63 年度： 5 大学（窒蘭工業大学, 群馬大学, 東 京農工大学, 名古屋大学, 岐阜大学)

平成元年度： 5 大学 (宇都宮大学, 茨城大学, 名古 屋工業大学, 九州工業大学, 佐賀大学) 
平成 2 年度： 5 大学（山梨大学, 王重大学, 京都工 芸絨維大学, 風山大学, 長崎大学)

富山大学に設置された地域共同研究センターでは開 設依頼共同研究が継続, 終了, 開始を織り混ぜながら 精力的に遂行され，62 年度 9 件，63 年度 15 件, 平成 元年度 18 件， 2 年度 18 件が刜施されている. 平成 2 年度実施中の共同研究テーマは次の通りである ${ }^{31}$.

\begin{tabular}{|c|c|c|}
\hline 研 究 課 題 & $\begin{array}{l}\text { 篅山大学研 } \\
\text { 究代表者 }\end{array}$ & 学外研究者 \\
\hline 半導体磁気センサの研究 & 龍山教授 & 北陸電攽工業 \\
\hline $\begin{array}{l}\text { 切削・研削における潤㳙成分 } \\
\text { の効果 }\end{array}$ & 高过教授 & 日華化学: \\
\hline ドリリングセンターの適応制 & 高过教授 & 菭田：業 \\
\hline 御に関寸る研究 & & エルコー \\
\hline $\begin{array}{l}\text { 酸化物高温超伝導体の電流・ } \\
\text { 熱流の磁場効果 }\end{array}$ & 森教授 & 北陸電方了 \\
\hline 機能性材料に関する研究 & 時澤教授 & アイシン軽金属 \\
\hline $\begin{array}{l}\text { 壬電音響素子の有限要素法解 } \\
\text { 析 }\end{array}$ & 山淵教授 & 富山村田製作所 \\
\hline $\begin{array}{l}\text { 気相合成ダイヤモンドのモル } \\
\text { フォロジーに関する研究 }\end{array}$ & 宫卜教授 & 不一越 \\
\hline 極低温鍛鋼管の開発 & 佐藤教授 & 太平洋製銅 \\
\hline 複合押出しに関する研究 & 蛑澤教授 & $\begin{array}{l}\text { 光川1アルミニ } \\
\text { ム」業 }\end{array}$ \\
\hline $\begin{array}{l}\mathrm{FA} \text { システムの対話型シーケ } \\
\text { ソサーのプログラム開発 }\end{array}$ & 米比教授 & 妾山マシン \\
\hline $\begin{array}{l}\text { 押出欠陥発生防止を目的とし } \\
\text { た最適押出条件に関する研究 }\end{array}$ & 時澤教授 & 富川軽金属工業 \\
\hline $\begin{array}{l}\text { マルチカラー液晶パネル用 } \\
\text { FI面米源の開登と関ナろ研 }\end{array}$ & 吇下教授 & 北陸電爻厂業 \\
\hline & & \\
\hline $\begin{array}{l}\text { Metalloproteases の酵素货 } \\
\text { 疫測定法 (EIA) の確视. }\end{array}$ & 泉崎教授 & 富:大薬品工業 \\
\hline $\begin{array}{l}\text { カラーLCD の高精細化に関 } \\
\text { する研究 }\end{array}$ & 女川教授 & 尘笔器製造 \\
\hline $\begin{array}{l}\text { ハソコンによるきょ5体内部 } \\
\text { の温度分布解析 }\end{array}$ & 中り教授 & イチカワ \\
\hline $\begin{array}{l}\text { 低コスト・省エネルギーを芙 } \\
\text { 現する屋根雪融雪 }\end{array}$ & 竹越教授 & $\begin{array}{l}\text { 富川県エンジニ } \\
\text { アリング協会 }\end{array}$ \\
\hline 低 $M g$ 押出合金の開発 & 池野助教授 & 新日軽 \\
\hline サーメット合金強靱化の研究 & 多々教授 & 不…越 \\
\hline
\end{tabular}

\section{4. 地域における産学協同研究}

地方の限られた地域で産学官の協同研究会を結成 し，技術レベルの向上に努めている北陸三県機電産学 官有志剆談会の実施状況を紹介寸る。これは各県別共 同研究テーマが決められ，これに不川県，富山県，福 井県の大学, 工業試験所, 企業各社が参加し, 北陸三 県協同研究をすすめるものである.

\begin{tabular}{c|c|c|c}
\hline 担 当 & 共同研究テーマ & 委員長 & 参加企業 \\
\hline 石川県 & $\mathrm{NC}$ 旋盤の生産性向上に関す & 金沢大学 & 7 社.
\end{tabular}

\begin{tabular}{|c|c|c|c|}
\hline & 万研究 & 安井教授 & \\
\hline 富山県 & $\begin{array}{l}\text { エキストパートシステムの研 } \\
\text { 究とその忘用 }\end{array}$ & $\begin{array}{l}\text { 富山大学 } \\
\text { 米田教授 }\end{array}$ & 9 社 \\
\hline 福井紫 & $\begin{array}{l}\text { 加エテーブルの高速送り制御 } \\
\text { に関する研究 }\end{array}$ & $\begin{array}{l}\text { 福井大学 } \\
\text { 豊島教授 }\end{array}$ & 7 社 \\
\hline
\end{tabular}

又, 平成 2 年度に新しい構想の北陸先端科学技術大 学院大学が北陸金沢に設置された。これは情報科学, 材料科学の分野にかかわる基礎研究を推進するととも に特に企業の技術者の大学院レベルの再教育を目標と した大学院のみを置く独立大学院である.

\section{5. おわりに}

産学協同研究もやっと地に足がついて, 年々増加し て来たことは喜ばしい限りである.

日本も米国も，新製品開発の $\mathrm{R} \& \mathrm{D}$ を含めて着手 から販売までの時間低減に努めている．米国では先端 技術は進歩が早くその基礎研究に企業は大学・学会に かなり期待している．そのため米国の NSF（National Science Foundation) は, 大学と企業の間を結び つける機関として機能し，NSFがスポンサーをして いるエンジニアリング・リサーチ・センターでは研究 テーマ・助成金設置の条件として大学と企業の緊密な 連携があることとしている. 又, 大学教官は週に 1 日，すなわち $20 \%$ の時間は企業のコンサルタントを し，産業界に貢献することを奨励している4).

このようにして社会で今何が問題になっているかを 教官が知り, 企業ニーズに対する研究, 教官自身の研 究及び教育に反映させている.

日本の企業側でも今後の経営環境の変化, すなわち 技術革新の進展, 地球環境・資源問題, 市場のグロー バル化等に対応して基礎研究・製品開発研究を強化し ていかねばならない.このためにもますます産学協同 研究の重要性が出てくることを銘記しなければならな い.

な拉, 日本機械学会研究協力部会, 材料連合フォー ラム等々数多くの諸団体により産学協同研究が進めら れているが，紙面の都合上紹介を割愛したことを打許 し願いたい。

\section{参 考 文 献}

1）大和田国男：産学協同研究, 精密機械, 50, 1 (1984).

2）文部省：教育白書, 平成 2 年度版, (1990).

3) 富山大学地域共同研究センター：概要パンフレット (1990).

4）テクノロジートランスファー研究所：先端技術者再教育 に関する訪米実態調査報告, (1990). 